\title{
PROTOTIPE RUANGAN NICU DENGAN SISTEM MONITORING SUHU DAN KELEMBABAN BERBASIS MINI SCADA JALUR MODBUS
}

\author{
Wisnu Broto ${ }^{1, a)}$, Agung Saputra ${ }^{2, b)}$, Allan Fadrius ${ }^{3, c)}$ \\ 1,2,3 Prodi Elektro Fakultas Teknik Universitas Pancasila, \\ Srengseng Sawah, Jagakarsa, Jakarta Selatan, Alamat, Pos. 12640 \\ Email: ${ }^{a)}$ wisnu.agni@gmail.com, ${ }^{\text {b) }}$ agungsap2002@yahoo.com, ${ }^{\mathrm{c})}$ allanfadrius@yahoo.com
}

\begin{abstract}
Abstrak
NICU merupakan suatu ruangan untuk mendukung perkembangan hidup bayi yang baru lahir. seperti ventilator mekanik, blue light therapy, portable rontgenography, echocardiography dan lain-lain. Dalam ruangan tersebut digunakan pula untuk melakukan perawatan pada bayi yang memiliki Pigmen bernama bilirubin dengan kadar atau level yang tinggi, bilirubin adalah faktor penyebab dari bayi kuning (ikterus). Untuk dapat mengatur bilirubin pada bayi serta mengendalikan infeksi nosokomial, maka ruang tersebut harus memenuhi standart yang ada, antara lain ruang NICU yang terisolasi dengan area umum, pembagian ruang infeksi dan non infeksi, scrub area, 1 wastafel tiap 3 bayi, jarak antara area perawatan bayi minimal $1,2 \sim 2,4$ meter, pengaturan suhu $\left(22 \sim 30^{\circ} \mathrm{C}\right)$ dan kelembaban (30 60\%) ruang NICU. Pada Project ini dibuat prototipe ruangan NICU dengan sistem untuk menjaga temperature dan kelembaban secara otomatis dengan mini SCADA melalui jalur modbus, yang di lengkapi dengan lampu UV untuk menurunkan tingkat bilirubin pada bayi. Hasil dari pengujian bahwa temperatur pada ruangan NICU mencapai $36.1^{\circ} \mathrm{C} \sim 37.8^{\circ} \mathrm{C}$ ketika lampu UV bekerja sesuai dengan tabel kerja dan temperatur tersebut memang di butuhkan untuk dapat menurunkan bilirubin pada bayi, kemudian fan dapat bekerja menurunkan temperatur yang telah berada diatas set point sehingga tetap terjaga pada range standart yang ada.
\end{abstract}

Kata Kunci: NICU, Bilirubin, Temperature dan kelembaban, Modbus, Mini SCADA.

\begin{abstract}
Abstrak
NICU is a room to support the development of newborns. such as mechanical ventilator, blue light therapy, portable rontgenography, echocardiography and others. In the room is also used to perform treatment in infants who have a pigment called bilirubin with high levels or levels, bilirubin is a contributing factor of jaundice (jaundice). In order to regulate bilirubin in infants as well as to control nosocomial infections, the space must meet the existing standards, including isolated NICU spaces with common areas, infections and noninfectious spaces, scrub areas, 1 washbasin every 3 infants, the distance between treatment areas infants at least $1.2 \sim 2.4$ meters, temperature setting $\left(22 \sim 30{ }^{\circ} \mathrm{C}\right)$ and humidity $(30 \sim 60 \%)$ NICU space. In this Project, NICU room prototype is designed to keep temperature and humidity automatically with mini SCADA through modbus line, which is equipped with UV lamp to decrease bilirubin level in infant. The result of testing that the temperature in the NICU room reached $36.1{ }^{\circ} \mathrm{C} \sim 37.8^{\circ} \mathrm{C}$ when the UV lamp works in accordance with the work table and the temperature is needed to reduce bilirubin in infants, then the fan can work to lower the temperature that has been above the set point so stay awake in the existing standard range.
\end{abstract}


Keywords: NICU, Bilirubin, Temperature and humidity, Modbus, Mini SCADA.

\section{PENDAHULUAN}

Di Indonesia Angka Kematian Bayi (AKB) masih tinggi, sekitar 56\% kematian terjadi pada periode yang sangat dini di masa neonatal yaitu dalam usia 28 hari pertama kehidupan. Sebagian besar kematian bayi terjadi pada 0-6 hari (78\%). Target MDG 2015 adalah menurunkan AKB menjadi 23 per 100 kelahiran hidup. Sedangkan hasil Survei Demografi dan Kesehatan Indonesia (SDKI) tahun 2007, AKB masih 34 per 1.000 kelahiran hidup jika dibandingkan dengan negara tetangga di Asia Tenggara seperti Singapura, Malaysia, Thailand, Filipina angka kematian bayi di negara Indonesia jauh lebih tinggi. ${ }^{[2]}$

NICU merupakan suatu ruangan untuk mendukung perkembangan hidup bayi yang baru lahir. Konsep perawatan ruangan ini didesain dengan mengacu pada standar internasional dan didukung dengan fasilitas dan alat-alat yang lengkap, seperti ventilator mekanik, Neopuff, Blue light therapy, Portable rontgenography, dan lain-lain.

Infeksi nosokomial atau infeksi yang diperoleh dari rumah sakit adalah infeksi yang tidak diderita pasien saat masuk ke rumah sakit melainkan setelah \pm 72 jam berada di tempat tersebut. ${ }^{[3]}$ Infeksi ini terjadi bila toksin atau agen penginfeksi menyebabkan infeksi lokal atau sistemik. ${ }^{[4]}$ Contoh penyebab terjadinya infeksi nosokomial adalah apabila dokter atau suster merawat seorang pasien yang menderita infeksi karena mikroorganisme patogen tertentu kemudian mikroorganisme dapat ditularkan ketika terjadi kontak. $^{[5]}$ Selanjutnya, apabila suster atau dokter yang sama merawat pasien lainnya, maka ada kemungkinan pasien lain dapat tertular infeksi dari pasien sebelumnya.

Kelompok yang juga sangat rentan terhadap infeksi nosokominal adalah anak-anak, terutama anakanak yang masih sangat muda yang baru lahir dan berada di ruangan NICU. Jumlah insiden di NICU sebanyak $14,2 \%$ atau 11,7 per 1000 per hari. Faktor resiko yang mendukung terjadinya infeksi nosokominal pada neonatus ini adalah berat lahir, usia genetasi kurang dan pemasangan infus. ${ }^{[6]}$ Secara epidemologi infeksi nosokominal yang umum terjadi pada anak-anak adalah infeksi pada saluran kemih $23 \%$, infeksi saluran nafas bawah $23 \%$, infeksi luka pembedahan $11 \%$, infeksi bloodstream $6 \% .{ }^{[7]}$ Sehingga perlu adanya ruang NICU yang steril guna menghindari infeksi, dan melakukan perawatan pada bayi yang memiliki pigmen bernama bilirubin dengan kadar atau level yang tinggi, bilirubin adalah faktor penyebab dari bayi kuning atau ikterus yang harus di kenali dan waspadai. Sebetulnya, setiap orang memiliki bilirubin dalam sel darah merahnya. Setiap jangka waktu tertentu sel darah merah akan mati dan menguraikan sel-selnya diantaranya menjadi bilirubin. Ketika bayi lahir, perkembangan hatinya belum sempurna sehingga belum dapat menjalankan fungsinya dengan baik. Akibatnya terjadi penumpukan bilirubin yang kemudian menyebabkan timbulnya warna kuning pada kulit bayi.

\section{METODE PENELITIAN}

\subsection{Neonatal Intensive Care Unit (NICU)}

Neonatal Intensive Care Unit (NICU) adalah ruangan khusus yang di lengkapi dengan peralatan atau fasilitas medis lainnya untuk merawat bayi baru lahir sampai usia 30 hari yang memerlukan pengobatan dan perawatan khusus di bawah pemantauan tim dokter dan juga digunakan pula untuk melakukan perawatan pada bayi yang memiliki Pigmen bernama bilirubin dengan kadar atau level yang tinggi.

Dalam ruangan NICU rentan sekali terhadap tumbuh berkembangnya infeksi nosokomial pada peralatan atau fasilitas yang ada di ruang tersebut, untuk menghindari tubuh berkembangnya infeksi nosokomial tersebut maka ruang tersebut harus memenuhi standar yang ada, antara lain ruangan harus terisolasi dengan area umum, pembagian ruang infeksi dan non infeksi, jarak tiap 3 bayi antara area perawatan bayi minimal 1,2 2,4 meter, pengaturan suhu $\left(22 \sim 30^{\circ} \mathrm{C}\right)$ serta kelembaban $(30-60 \%)$, dan lampu UV dengan intensitas yang cukup. ${ }^{[8]}$ Dimensi ruangan sesungguhnyaa seperti terlihat pada gambar 2.1 


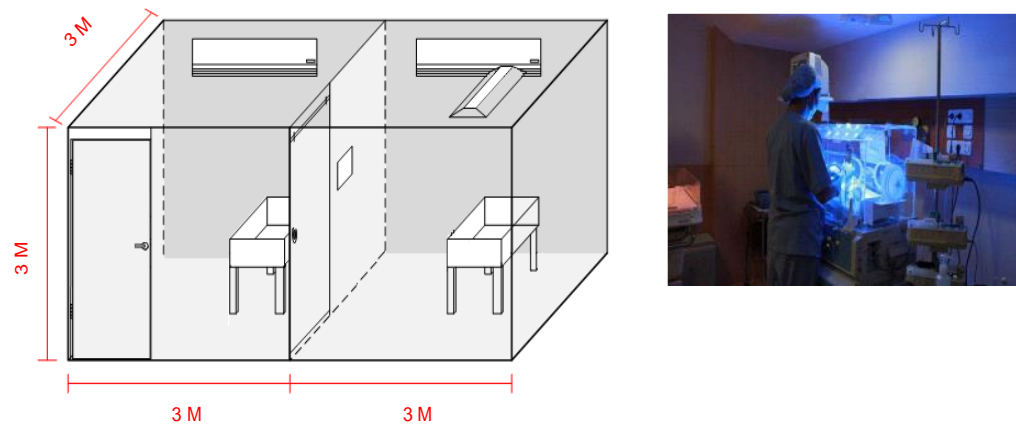

Gambar 2.1 Ruangan NICU

\subsection{Bilirubin}

Bilirubin adalah zat yang terbentuk sebagai akibat dari proses pemecahan hemoglobin atau (zat merah darah) dalam tubuh. Selanjutnya mengalami proses konjugasi di lever, dan akhirnya dieksresikan (dikeluarkan) oleh lever ke empedu kemudian ke usus. Ikterus normal timbul pada hari kedua dan ketiga dan tidak disebabkan oleh kelainan apapun, kadar Bilirubin darah tidak lebih dari kadar yang membahayakan yang tidak mempunyai potensi menimbulkan kecatatan pada bayi.

\subsection{Faktor kadar tinggi bilirubin pada bayi}

Kadar bilirubin yang lebih tinggi dan lebih lama dari sakit kuning biasa dapat terjadi karena bayi tidak mendapatkan cukup ASI. Hal ini dapat disebabkan karena produksi ASI membutuhkan waktu lebih lama daripada biasanya (tapi jika bayi menyusu dengan baik dalam beberapa hari pertama seharusnya hal ini bukanlah masalah), atau karena kebiasaan di rumah sakit yang membatasi menyusui, atau karena, biasanya, pelekatan bayi tidak baik sehingga bayi tidak mendapatkan cukup ASI yang tersedia Ketika bayi mendapatkan sedikit ASI, buang air besar cenderung menjadi sedikit dan jarang karena bilirubin yang berada di usus bayi terserap kembali ke dalam darah dan bukannya dibuang saat buang air besar. ${ }^{[9]}$

\subsection{Cara menentukan kadar bilirubin pada bayi}

Bayi yang baru lahir biasanya memliki kadar bilirubin yang berbeda beda, sehingga perlu adanya beberapa pemeriksaan klinis Dengan melakukan pemerikasaan klinis melalui Ikterus ialah :

- Ikterus muncul pertama di daerah wajah, menjalar ke arah kaudal tubuh dan ektremitas. Ikterus adalah pewarnaan kuning yang tampak pada sklera dan kulit yang disebabkan oleh penumpukan bilirubin.

- Tekan kulit dengan ringan menggunakan jari tangan untuk memastikan warna kulit dan jaringan subkutan.

○ Hari ke 1, tekan pada ujung hidung atau dahi

- Hari ke 2, tekan pada lengan atau tungkai

- Hari ke 3 dst, tekan pada tangan dan kaki

Tabel 2.1 Daerah Ikterus dan perkiraan kadar bilirubin

\begin{tabular}{|c|l|l|}
\hline $\begin{array}{c}\text { Derajat } \\
\text { ikterus }\end{array}$ & \multicolumn{1}{|c|}{ Daerah Ikterus } & $\begin{array}{l}\text { Perkiraan kadar } \\
\text { bilinubin }\end{array}$ \\
\hline I & Kepala dan leher & $5,0 \mathrm{mg} \%$ \\
\hline II & Sampai badan atas (diatas umbilikus) & $9,0 \mathrm{mg} \%$ \\
\hline III & $\begin{array}{l}\text { Sampai badan bawah (dibawah umbilikus) } \\
\text { hingga tungkai atas (diatas lutut) }\end{array}$ & $11,4 \mathrm{mg} /$ dl \\
\hline IV & Sampai lengan, tungkai bawah lutut & $12,4 \mathrm{mg} /$ dl \\
\hline
\end{tabular}




\subsection{Modbus}

Modbus ini merupakan protokol komunikasi serial untuk diaplikasikan ke dalam Programmable Logic Controllers (PLC). Modbus mampu menghubungkan 247 peralatan (slave) dalam satu jaringan atau master, misalnya sebuah sistem yang melakukan pengukuran suhu dan kelembapan dan mengirimkan hasilnya ke sebuah komputer. Modbus sering digunakan untuk menghubungkan komputer pemantau dengan Remote Terminal Unit (RTU) pada sistem Supervisory Control And Data Acquisition (SCADA). Modbus memiliki beberapa jenis type Modbus yaitu Modbus Serial (RTU \& ASCII), Modbus TCP/IP, Modbus +. Dalam tugas akhir ini penulis menggunakan type Modbus RTU.

Tabel 2.2 Tabel penyimpanan data pada Modbus

\begin{tabular}{lccl}
\hline Primary tables & Object type & \multicolumn{1}{c}{ Type of } & \multicolumn{1}{c}{ Comments } \\
\hline Coils & Single bit & Read-Write & $\begin{array}{l}\text { Master dan slave bisa } \\
\text { merubah data coil }\end{array}$ \\
Discretes Input & Single bit & Read-Only & $\begin{array}{l}\text { Data hanya bisa di rubah } \\
\text { oleh sleve } \\
\text { Data hanya bisa di rubah } \\
\text { oleh sleve }\end{array}$ \\
Input Register & 16-bit word & Read-Only & $\begin{array}{l}\text { Master dan } \text { slave bisa } \\
\text { merubah data register }\end{array}$ \\
Holding Register & 16-bit word & Read-Write & \\
\hline
\end{tabular}

\subsubsection{Modbus RTU}

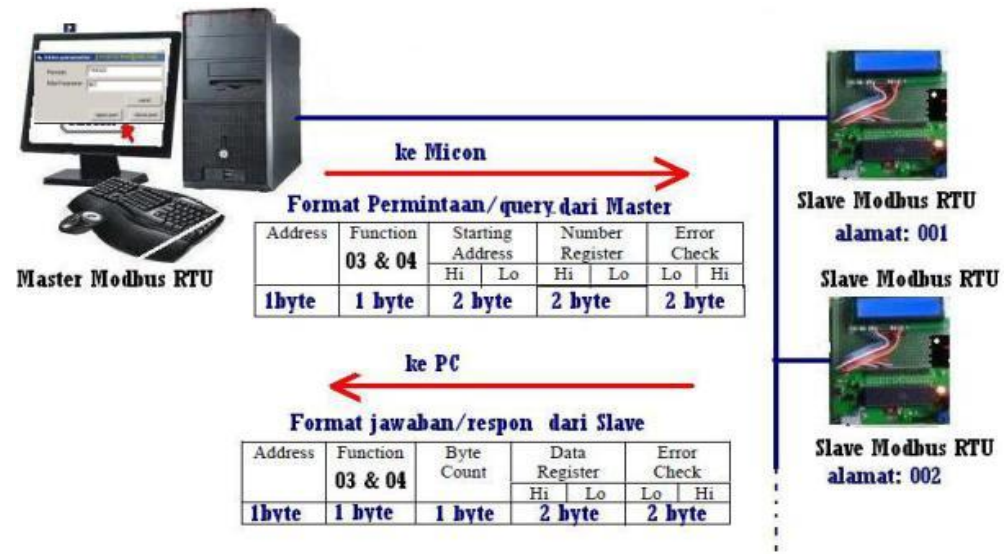

Gambar 2.2 Protokol Modbus master slave-Modbus ${ }^{[10]}$

Gambar di atas merupakan varian Modbus yang ringkas dan digunakan pada komunikasi serial. Format RTU dilengkapi dengan mekanisme cyclic redundancy error (CRC) untuk memastikan keandalan data. Modbus RTU merupakan implementasi protokol Modbus yang paling umum digunakan. Setiap frame data dipisahkan dengan periode idle (silent).

Protokol komunikasi Modbus Serial ini mengatur cara-cara dan format komunikasi serial (RS232 atau RS485) antara master dengan slave ( master atau slave dapat berupa PLC, microcontroller, smart device dan lain-lain). Jaringan Modbus terdiri dari master dan beberapa slave, master yang berinisiatif memulai komunikasi antara lain menulis data, membaca data dan mengetahui status slave. Permintaan master disebut juga sebagai request atau query. slave hanya bersifat pasif atau menunggu atau dengan kata lain slave hanya merespon jika ada permintaan atau query dari master.

Jumlah slave dalam protokol Modbus bisa sebanyak 247 slave. Slave dapat berupa PLC, peralatan elektronik, controller, sensor dan lain-lain. seperti pada gambar 2.3 di bawah ini. 


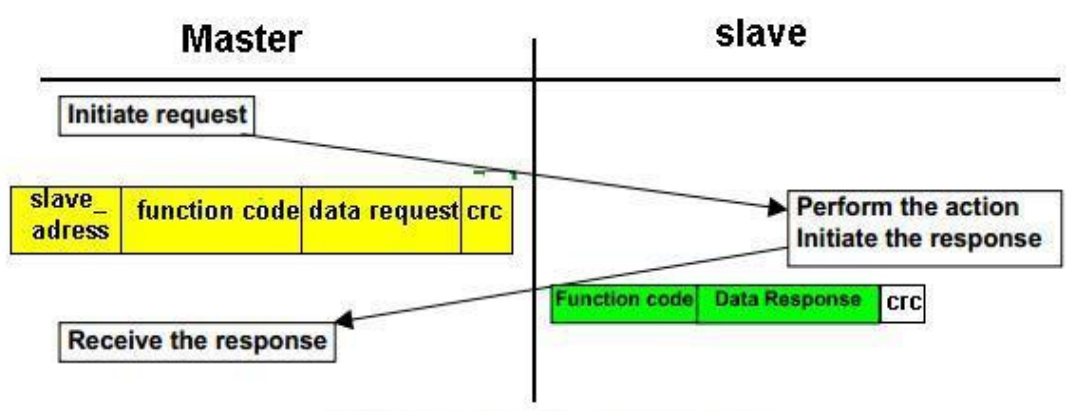

Gambar 2.3 Frame Modbus transaction

Pada protokol Modbus terdapat 4 buah jenis penyimpanan data dengan panjang masing-masing 16 bit. seperti dijelaskan pada tabel 2.2 dibawah ini.

\subsection{Sensor DHT11}

DHT11 termasuk sensor yang memiliki kualitas terbaik, dinilai dari respon, pembacaan data yang cepat, dan kemampuan anti-interference. Ukurannya yang kecil, dan dengan transmisi sinyal hingga 20 meter, membuat produk ini cocok digunakan untuk banyak aplikasi-aplikasi pengukuran suhu dan kelembaban. Merupakan jenis sensor suhu atau temperatur serta kelembapan pada suatu ruang. THD (Temperature Humidity Double) merupakan salah satu jenis sensor suhu yang sering digunakan dalam berbagai rangkaian ataupun peralatan listrik dan Elektronika yang berkaitan dengan Suhu (Temperature), Gambar sensor DHT11 dapat terlihat pada gambar 2.12.

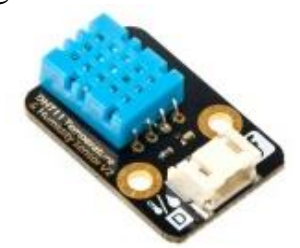

Gambar 2.4 Sensor DHT11

\subsection{Mikrokontroller AVR ATMEGA 16}

Mikrokontroler ATMega 16 merupakan salah satu mikrokontroler buatan AVR yang memiliki fasilitas-fasilitas yang cukup lengkap, diantaranya :

a. Flash adalah suatu jenis Read Only Memory yang biasanya diisi dengan program hasil buatan manusia yang harus dijalankan oleh mikrokontroler.

b. RAM (Random Acces Memory) merupakan memori yang membantu CPU untuk penyimpanan data sementara dan pengolahan data ketika program sedang running.

c. EEPROM (Electrically Erasable Programmable Read Only Memory) adalah memori untuk penyimpanan data secara permanen oleh program yang sedang running.

d. Port $I / O$ adalah kaki untuk jalur keluar atau masuk sinyal sebagai hasil keluaran ataupun masukan bagi program.

e. Timer adalah modul dalam hardware yang bekerja untuk menghitung waktu/pulsa.

f. UART (Universal Asynchronous Receive Transmit) adalah jalur komunikasi data khusus secara serial asynchronous.

g. PWM (Pulse Width Modulation) adalah fasilitas untuk membuat modulasi pulsa.

h. ADC (Analog to Digital Converter) adalah fasilitas untuk dapat menerima sinyal analog dalam range tertentu untuk kemudian dikonversi menjadi suatu nilai digital dalam range tertentu.

i. SPI (Serial Peripheral Interface) adalah jalur komunikasi data khusus secara serial secara serial synchronous.

j. ISP (In System Programming) adalah kemampuan khusus mikrokontroler untuk dapat diprogram langsung dalam sistem rangkaiannya dengan membutuhkan jumlah pin yang minimal.

\subsection{SCADA(Supervisory Control \& Data Acquisition)}


Merupakan sistem kendali industri berbasis komputer yang dipakai untuk pengontrolan suatu proses, selain itu juga berfungsi sebagai penyampaian data, proses kegiatan dan monitoring, fungsi control dan penghitungan dan pelaporan.

Suatu sistem SCADA biasanya terdiri dari antarmuka manusia mesin (Human-Machine Interface), unit terminal jarak jauh yang menghubungkan beberapa sensor pengukuran dalam proses-proses di atas, sistem pengawasan berbasis komputer untuk pengumpul data, infrastruktur komunikasi yang menghuhungkan unit terminal jarak jauh dengan sistem pengawasan, dan PLC (Programmable Logic Controller).

\subsection{RTC ( Real Time Clock)}

Merupakan sebuah IC yang memiliki fungsi untuk menghitung waktu, mulai dari detik, menit, jam, tanggal, bulan, serta tahun.
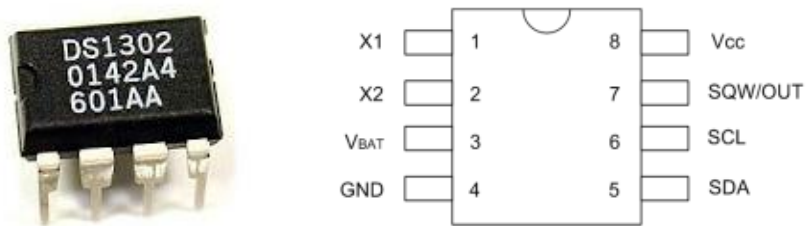

Gambar 2.5 RTC ( Real Time Clock )

\subsection{Relay}

Bagian titik kontak Relay dibagi menjadi 2 bagian yaitu bagian kontak utama dan kontak bantu yaitu :

- Bagian kontak utama gunanya untuk menghubungkan dan memutuskan arus listrik bagian yang menuju beban /pemakai.

- Bagian kontak bantu gunanya untuk menghubungkan dan memutuskan arus listrik ke bagian yang menuju bagian pengendali.

Kontak Bantu mempunyai 2 kontak yaitu kontak hubung (NC) dan kontak putus (NO) menandakan masing-masing kontak dan gulungan spool.
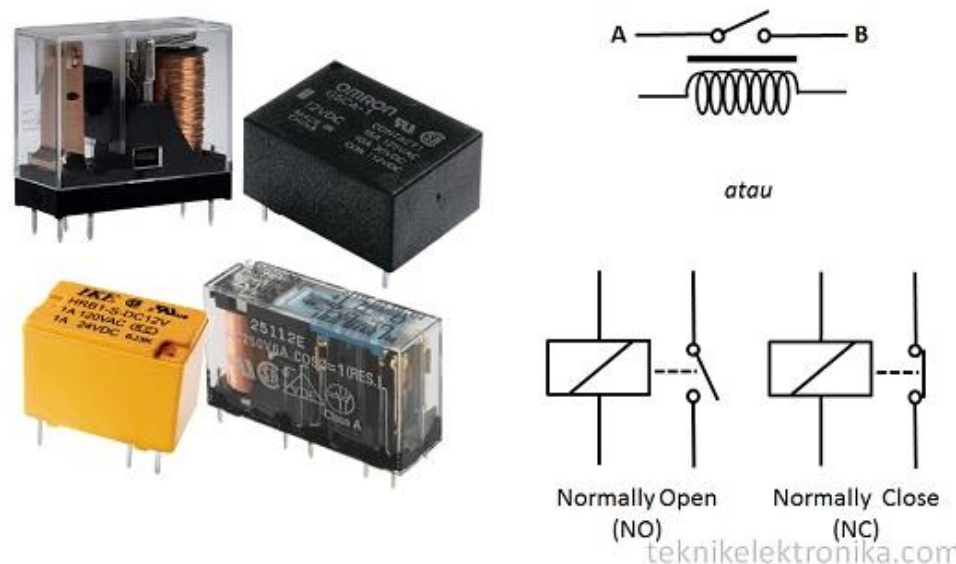

Gambar 2.6 Bentuk Fisik dan Simbol Relay ${ }^{[11]}$

\subsection{Prototipe pada ruangan NICU}

ini memiliki sistem monitoring dan kontrol temperatur, dengan menggunakan sensor DHT11 untuk mendeteksi temperatur serta kelembaban pada ruangan tersebut, lalu data tersebut akan di kirimkan menuju LCD dan menuju PC melalui jalur modbus sehingga dari PC bisa memeberikan inputan set point temperatur kepada mikrokontroler untuk diproses sebagai perintah kerja output pada ruangan NICU, seperti di jelaskan Blok diagram alat pada gambar di bawah ini : 


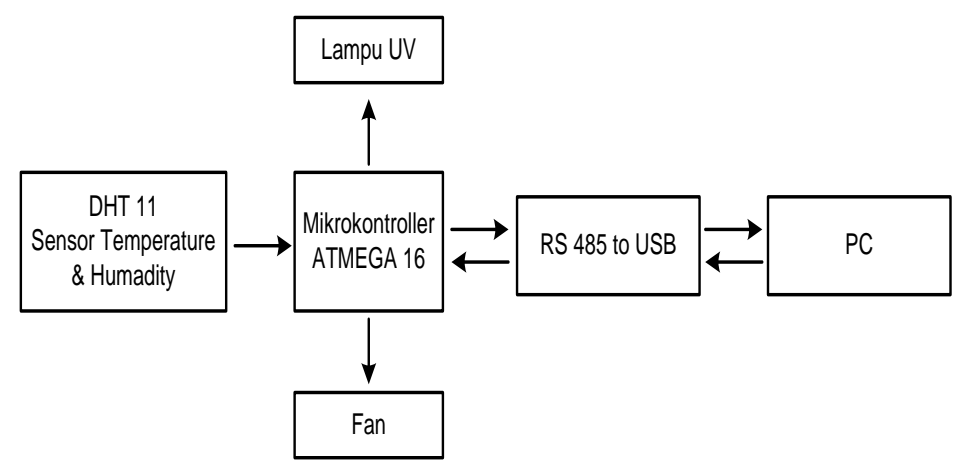

Gambar 2.7 Blok Diagram Sistem

\section{HASIL DAN ANALISA PROTOTIPE RUANGAN NICU}

Prototipe ruangan NICU dibuat terpisah menjadi 2 ruangan menggunakan kotak dengan bahan acrylic, pada ruangan NICU 1 di lengkapi dengan fan dan ruangan NICU 2 dengan fan dan lampu UV, setiap ruangan memiliki dua sistem kerja yang berbeda dengan fungsi yang berbeda pula, terlihat seperti pada gambar di bawah ini.

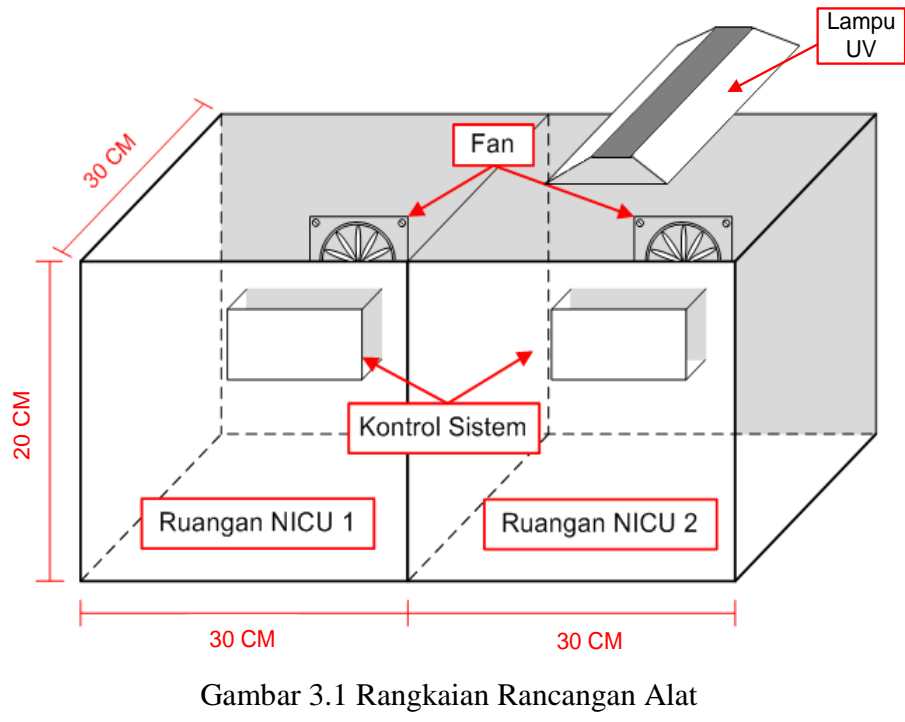

Berikut pada gambar 3.1 merupakan dimensi kedua ruangan NICU di rumah sakit yang akan dibuat:

- Dimensi Ruangan NICU 1 :

Panjang $=30 \mathrm{~cm}$, Lebar $=30 \mathrm{~cm}$, Tinggi $=20 \mathrm{~cm}$

- Dimensi Ruangan NICU 2 :

Panjang $=30 \mathrm{~cm}$, Lebar $=30 \mathrm{~cm}$, Tinggi $=20 \mathrm{~cm}$

\subsection{Perencanaan Input}

Sensor menggunakan DHT11 berfungsi untuk mengetahui temperatur dan kelembaban pada ruangan NICU. Berikut adalah perancangan blok diagramnya:

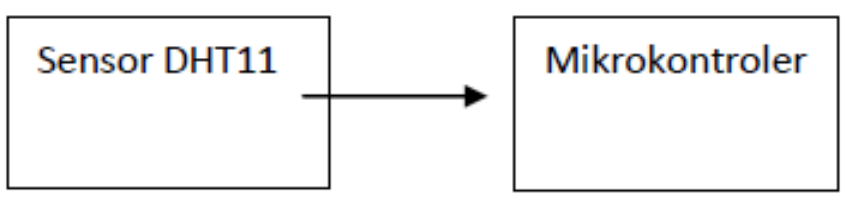

Gambar 3.2 Diagram Blok Sensor Ruangan NICU 


\subsection{Perencanaan Proses}

Ruangan NICU diperlukan proses pengolahan data tegangan analog menjadi digital yang sudah tersedia di PORT A bit ke 0 Mikrokontroler, untuk komunikasi mikrokontroler dengan PC digunakan komunikasi converter transmiter RS485 to USB serial. Komunikasi serial terdapat pada PORT-D mikrokontroler tepatnya di PORT-D bit 0 untuk Rx dan bit 1 untuk Tx.

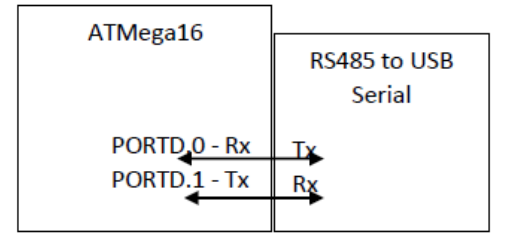

Gambar 3.3 Diagram Blok Sistem Komunikasi Serial

\subsection{Perencanaan Output}

Alat ini memiliki dua perencanaan output, diantaranya pada ruangan NICU-1 dan 2, pada perencanaan output ruangan NICU-1 terdapat sebuah output fan yang dapat menjaga temperatur ruangan NICU tersebut yang bekerja secara otomatis dengan perintah aktif oleh mikrokontroler. Fan ini memiliki tegangan operasional $220 \mathrm{~V}_{\mathrm{AC}}$ sehingga membutuhkan driver relay dari mikrokontroler terhadap fan untuk mengaktifkan dan mengnonaktifkan fan.

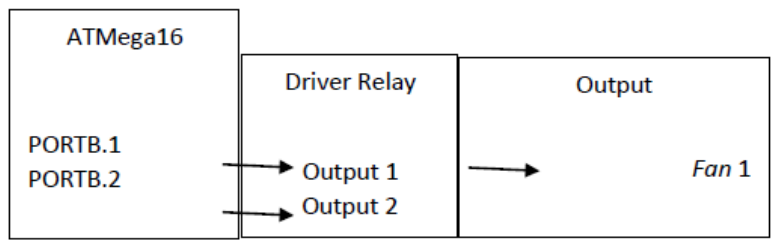

Gambar 3.4 Diagram Blok Ouput Ruang NICU 1

Pada perencanan output ruangan NICU 2 ada lampu UV yang di gunakan sebagai pemberi sinar UV pada bayi dengan kondisi bilirubin yang telah di tentukan, bekerja secara otomatis dengan perintah aktif oleh mikrokontroler.

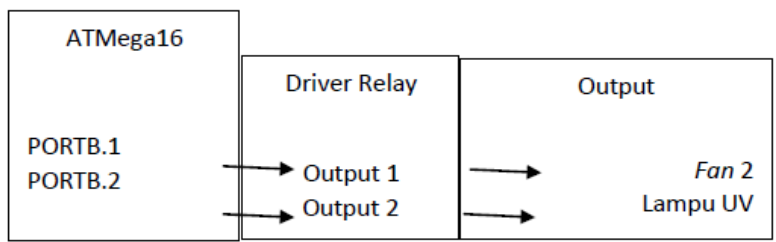

Gambar 3.5 Diagram Blok Ouput Ruang NICU 2

\subsection{Bentuk Rancangan Alat}

Dari gambar 3.6 dapat di lihat sebuah perancangan atau rangkaian sistem kontrol guna megatur kerja media pendingin dan penerangan ( Lampu UV ) serta memonitor kondisi ruangan NICU. Terlihat bahwa sensor DHT11 merupakan sensor yang akan berperan sebagai alat pendeteksi temperatur dan kelembaban ruangan NICU kemudian data tersebut akan di proses oleh mikrokontroler dan di tampilkan oleh LCD dan mini SCADA. 


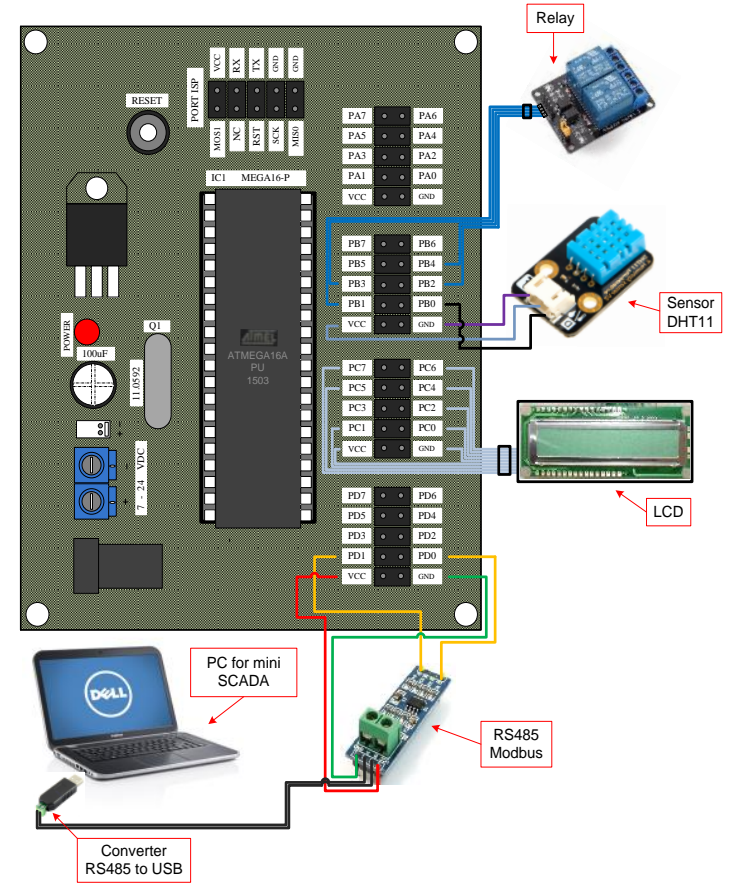

Gambar 3.6 Bentuk Rancangan Alat

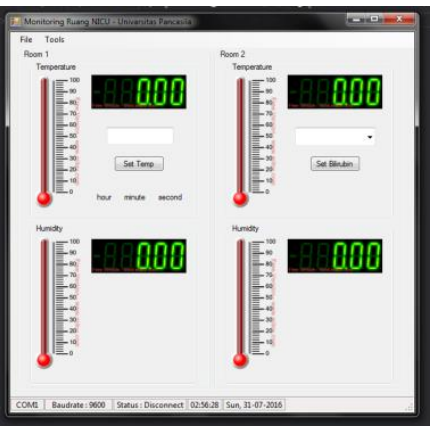

Gambar 3.7 Tampilan pada mini SCADA

\subsection{Flowchart Kerja NICU}

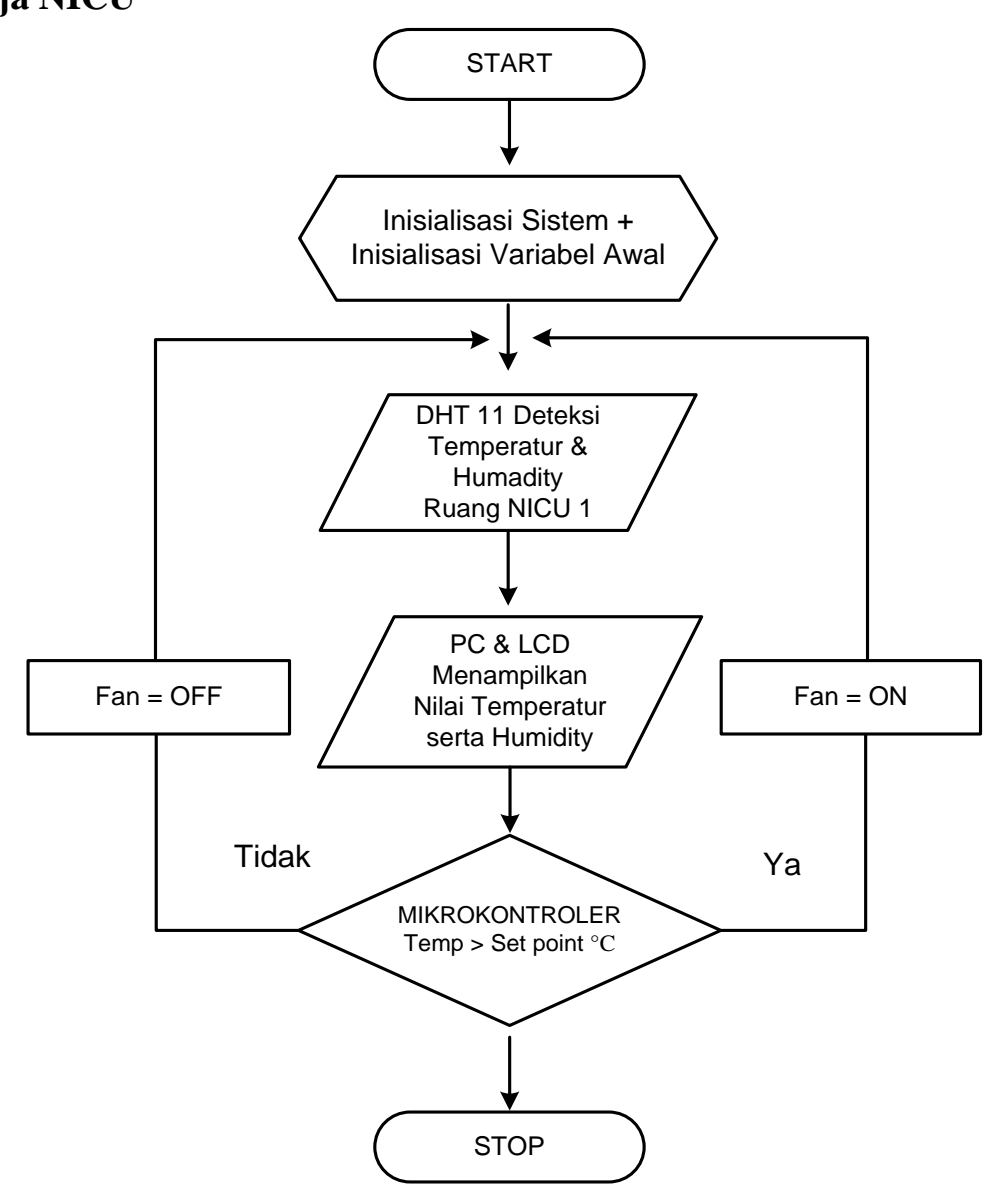

Gambar 3.8 Flowcart Kerja NICU 
Penjelasan Flow Chart ruangan NICU :

- DHT11 Sensor akan mendeteksi temperatur dan kelembaban pada ruangan NICU tersebut.

- Kemudian data yang di dapat dari sensor DHT11 akan di proses oleh mikrokontroler, dan akan di tampilkan oleh mini SCADA dan juga LCD

- Data dari mikrokontroler di transfer meuju PC melalui jalur komunikasi RS485 Modbus,

- Setelah PC menampilkan nilai temperatur dan kelembaban, dan perawat akan memberikan input set point untuk ruangan tersebut.

- Setelah itu fan akan bekerja di atas set point, hingga berada di bawah atau pada set point yang telah di tentukan.

\subsection{Pengujian Alat}

Dari hasil pengujian peralatan serta komponen-komponen pendukung dan pengujian sistem secara kelesuruhan dapat di tarik beberapa ringkasan analisa yang di dapat diantaranya:

1. Pengujian peralatan serta komponen pendukung

a) Pada pengujian catu daya nilai tegangan $11,79 \mathrm{Vdc}$ untuk tegangan power supply. Untuk tegangan output regulator menunjukan hasil dengan nilai 4,98 Vdc yang memiliki selisih $-0,2$ volt dari perancangan yaitu sebesar $5 \mathrm{Vdc}$. Kemudian untuk tegangan supply fan menunjukan hasil 11,73 Vdc yang memiliki selisih $-0,27$ volt dari perancangan yaitu sebesar 12 Vac.

b) Pengujian Sensor DHT11 temperatur dan kelembaban memiliki rata-rata selisih dari nilai temperatur $0.9^{\circ} \mathrm{C}$ dan kelembaban $0.8 \%$. sesuai dengan spesifikasi error yang di miliki sensor DHT11 yakni $\pm 2^{\circ} \mathrm{C}$ untuk temperature dan $2 \%$ untuk kelembaban, sehingga dapat di katakan bahwa sensor ini masih di dalam standart batas toleransi.

c) Pengujian LCD Menampilkan informasi nilai temperatur $30^{\circ} \mathrm{C}$ dan kelembaban $51 \%$ yang menandakan bahwa LCD dapat menampilakan informasi dengan baik.

d) Pengujian Fan menunjukan hasil dengan nilai $11.73 \mathrm{Vdc}$ untuk fan 1 dan $11.73 \mathrm{Vdc}$ untuk fan 2 memiliki selisih $0.27 \mathrm{Vdc}$ dari supply tegangan fan $12 \mathrm{Vdc}$.

e) Pengujian Lampu UV menunjukan hasil dengan nilai 193.2 Vac untuk lampu UV memiliki selisih $26.8 \mathrm{Vdc}$ dari supply tegangan fan $220 \mathrm{Vac}$

2. Pengujian sistem secara keseluruhan

a) Pengujian Ruangan NICU 1, bahwa thermometer memiliki rata-rata selisih dari nilai temperatur $0.7^{\circ} \mathrm{C}$ dan kelembaban $0.9 \%$. sesuai dengan spesifikasi eror yang di miliki sensor DHT11 yakni $\pm 2{ }^{\circ} \mathrm{C}$ untuk temperature dan $2 \%$ untuk kelembaban, sehingga dapat di katakan bahwa sensor ini masih di dalam batas toleransi, kemudian fan bekerja sesuai set point yang telah di tentukan, sehingga dapat di simpulkan bahwa proses sistem pada ruang NICU 1 sesuai dengan sistem kerja.

b) Pengujian Ruangan NICU 2, bahwa nilai temperatur ketika pada level yang telah di tentukan masih berada batas standar phototheraphy untuk bayi $36.1{ }^{\circ} \mathrm{C}$ and $37.8^{\circ} \mathrm{C}$. dan fan bekerja setelah lampu UV padam, sehingga dapat di katakan ruangan NICU 2 sesuai dengan sistem kerja.

\section{SIMPULAN}

Berdasarkan perancangan dan pengujian yang telah di lakukan maka dapat disimpulkan bahwa:

1. Pengujian peralatan serta komponen pendukung

a) Pada pengujian catu daya nilai tegangan $11,79 \mathrm{Vdc}$ untuk tegangan power supply. Untuk tegangan output regulator menunjukan hasil dengan nilai 4,98 Vdc yang memiliki selisih $-0,2$ volt dari perancangan yaitu sebesar $5 \mathrm{Vdc}$. Kemudian untuk tegangan supply fan menunjukan hasil 11,73 Vdc yang memiliki selisih $-0,27$ volt dari perancangan yaitu sebesar 12 Vac.

b) Pengujian Sensor DHT11 temperatur dan kelembaban memiliki rata-rata selisih dari nilai temperatur $0.9^{\circ} \mathrm{C}$ dan kelembaban $0.8 \%$. sesuai dengan spesifikasi error yang di miliki sensor DHT11 yakni $\pm 2{ }^{\circ} \mathrm{C}$ untuk temperature dan $2 \%$ untuk kelembaban, sehingga dapat di katakan bahwa sensor ini masih di dalam standart batas toleransi.

c) Pengujian LCD Menampilkan informasi nilai temperatur $30^{\circ} \mathrm{C}$ dan kelembaban $51 \%$ yang menandakan bahwa LCD dapat menampilakan informasi dengan baik. 
d) Pengujian Fan menunjukan hasil dengan nilai $11.73 \mathrm{Vdc}$ untuk fan 1 dan $11.73 \mathrm{Vdc}$ untuk fan 2 memiliki selisih $0.27 \mathrm{Vdc}$ dari supply tegangan fan $12 \mathrm{Vdc}$.

e) Pengujian Lampu UV menunjukan hasil dengan nilai 193.2 Vac untuk lampu UV memiliki selisih $26.8 \mathrm{Vdc}$ dari supply tegangan fan $220 \mathrm{Vac}$

2. Pengujian sistem secara keseluruhan

a) Pengujian Ruangan NICU 1, bahwa thermometer memiliki rata-rata selisih dari nilai temperatur $0.7^{\circ} \mathrm{C}$ dan kelembaban $0.9 \%$. sesuai dengan spesifikasi eror yang di miliki sensor DHT11 yakni $\pm 2{ }^{\circ} \mathrm{C}$ untuk temperature dan $2 \%$ untuk kelembaban, sehingga dapat di katakan bahwa sensor ini masih di dalam batas toleransi, kemudian fan bekerja sesuai set point yang telah di tentukan, sehingga dapat di simpulkan bahwa proses sistem pada ruang NICU 1 sesuai dengan sistem kerja.

b)Pengujian Ruangan NICU 2, bahwa nilai temperatur ketika pada level yang telah di tentukan masih berada batas standar phototheraphy untuk bayi $36.1^{\circ} \mathrm{C}$ and $37.8^{\circ} \mathrm{C}$. dan fan bekerja setelah lampu UV padam, sehingga dapat di katakan ruangan NICU 2 sesuai dengan sistem kerja

\section{UCAPAN TERIMAKASIH}

Penulis dan team mengucapkan terimakasih kepada Prodi Elektro Fakultas Teknik Universitas

Pancasila yang telah banyak membantu dalam peminjaman tool dan ruang laboratorium.

\section{REFERENSI}

[1] Beck, Wojdyla, Say, et al, 2010. The worldwide incidence of preterm birth

[2] Depkes RI, 2011. Profil Kesehatan Indonesia 2011. http://www.depkes.go.id.

[3] Karen Adams, Janet M. Corrigan (2003). Priority Areas for National Action: Transforming Health Care Quality. National Academies Press. Karen Adams \& Janet M. Corrigan, 2003.

[4] Karen Adams, Janet M. Corrigan (2003). Priority Areas for National Action: Transforming Health Care Quality. Karen Adams \& Janet M. Corrigan, 2003.

[5] Steven Jonas, Raymond L. Goldsteen, Karen Goldsteen (2007). Introduction to the US health care system. Springer Publishing Company.Lachassinne, Letamendia-Richard \& Gaudelus, 2005.

[6] Price, S. A. dan Wilson, L. M. (2006). Patofisiologi : Konsep Klinis Proses-Proses Penyakit, Edisi 6, Volume 1. Jakarta: EGC.

[7] https://superpremature.wordpress.com/2011/09/20/mengenal-nicu/ blog NICU RS Husada Utama Surabaya (tanggal akses 20 April 2016).

[8] http://www.amazine.co/23924/penyebab-gejala-pengobatan-kadar-bilirubin-tinggi// （tanggal akses 2 Juni 2016).

[9] Jack Newman MD, FRCPC, IBCLC and Edith Kernerman, IBCLC, 2008, 2009. Visual Guide to Breastfeeding

[10] Huda Miftahul, ProtokolKomunikasi Modbus RTU pada Sistem Otomasi Industri, LPP Kampus Yogjakata 
